\title{
A Rare Case of Heterophagus Twin Presented as A Footling Breech
}

\author{
Gnanarathne DMST ${ }^{1}$, PereraWME ${ }^{2}$, Sumanathissa RPJ $^{3}$
}

\section{INTRODUCTION}

Heterophagus twining is an extremely rare condition which has an estimated incidence of less than 0.1 in 100,000 live births. ${ }^{1}$ It is a type of conjoined twins, where one twin of the pair is malformed. The defective twin is termed the "parasite" and the intact twin is termed the "autosite". Other terms used to describe this condition are "asymmetric conjoined," "partial (or incomplete) conjoined," "parasitic," and "exoparasitic". ${ }^{2}$

As this clinical situation is rare perhaps it may not be possible to experiences this type of patient in a life time of an obstetrician, thus we report a case of a heterophagus twin with an abnormal growth similar to a limb presented as a footling breech.

\section{CASE REPORT}

A 26-year-old lady in her second pregnancy at the POA of 36 weeks was transferred from a local hospital for further management of breech presentation in labour. She had an uncomplicated antenatal period. However, she had not undergone ultrasound scan assessment except for a dating scan at $12^{\text {th }}$ week which was found to be normal.

An emergency caesarian section was performed due to footling breech presentation.

The baby was found to have an abnormal growth similar to another limb which was attached to the back of the body (Figure 1 and 2).

${ }^{1}$ Consultant Obstetrician and Gynecologist,
District Base Hospital, Hatton Dickoya.
${ }^{2}$ Registrar in Obstetrics and Gynecology,
Teaching Hospital Kandy.
${ }^{3}$ Registrar in Obstetrics and Gynecology,
Teaching Hospital Kandy.
Correspondence: D.M.S.T. Gnanarathne
MBBS,MD,MRCOG
E-mail: ssampatht@yahoo.com
Competing interests: The authors report no
conflict of interest

Figure 1

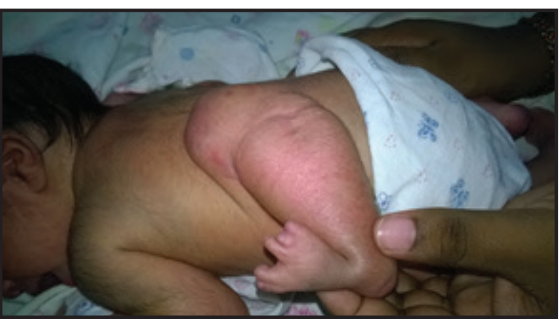

Figure 2

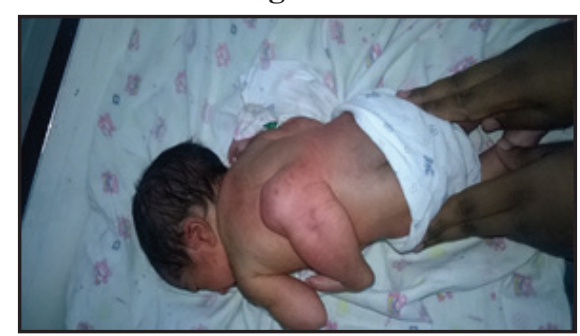

Further investigations were done with imaging studies. MRI of brain and thoracolumbar spine of the neonate revealed an open spinal dysraphism of lower thoracic and upper lumbar vertebra with a myelomeningocoele at the thoracolumbar junction (Figure 3\&4).

There was an accessory limb attached to the meningomyelocoele sac. It consisted of a long bone which could be the femur. Tibia and fibula were not visualized. The rudimentary foot was noted. Limb composed of a lipomatous mass surrounding the long bone and covered by skin. No muscles were noted around the bone. Nerve conduction studies did not reveal any functional motor units in the extra limb.

\section{DISCUSSION}

The pathophysiology of conjoint twins and heterophagus twinning is not clearly understood. Embryonic "fission" (incomplete fission of the blastocyst inner cell mass during the primitive streak stage, 13 to 15 days post fertilization, results in 2 centers of axial growth that retain a connection at some point) and "fusion" ( 2 originally distinct inner cell masses that coalesce secondarily at a later stage)

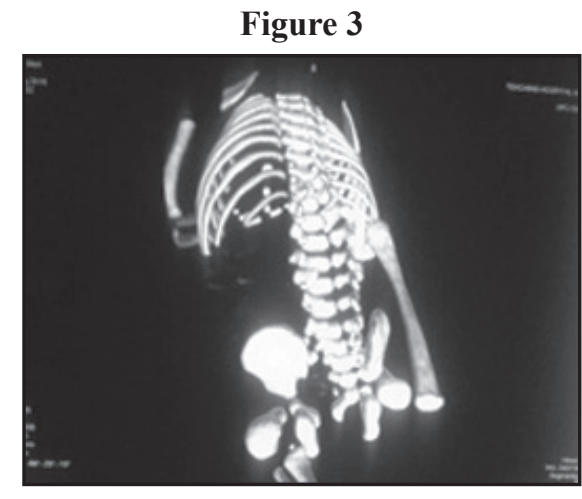

are the two widely accepted theories of forming conjoint twins. ${ }^{2}$

It is thought that vascular compromise causes tissue of the parasitic twin to become dependent on collaterals derived from the autosite. Compromised portion of the parasite undergoes selective ischaemic atrophy. $^{2}$

Depending on the type of connection between twins, different variants of heterophagus twins are described. Most frequent variety involves union between the thorax and umbilicus termed "epigastric" or "omphalophagus". Fusion at the hip and spine is termed "ischiophagus" and "rachiphagus" accordingly and least reported variety is "craniophagus" twins where fusion is at the heads. ${ }^{2}$

The above case is a rachiphagus parasitic twin where the connection is sited at the thoraco lumbar spine region of the autosite. There was no functional motor activity in the accessory limb. This finding coincides with similar findings described in other reported cases.

Limbs were described in $38 \%$ of cases since 2001. None of the parasites showed any capacity for movements. ${ }^{2}$ One case has reported absent musculature. ${ }^{4}$ It is thought that deficiency of nerve supply resulted in failure of myoblast differentiation and skeletal muscle development. ${ }^{3}$

The autosites are also known to have certain malformations. Congenital cardiac

(1) This is an open-access article distributed under the terms of the Creative Commons Attribution License, which permits unrestricted use, distribution, and reproduction in any medium, provided the original author and source are credited. 
Figure 4

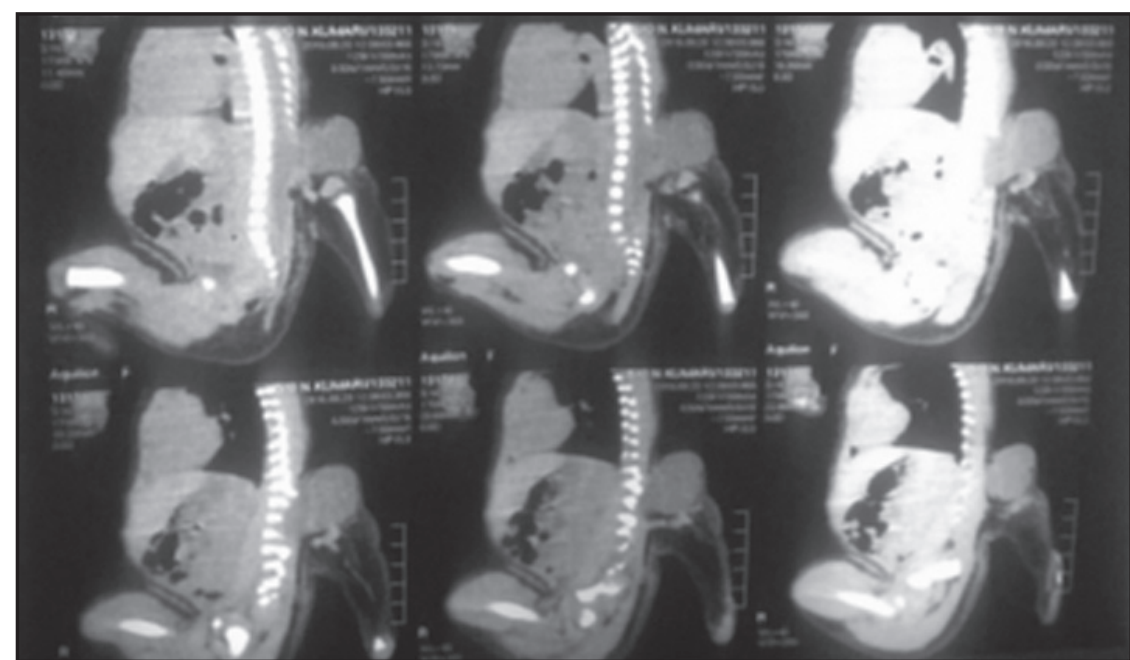

malformations are found in $23 \%$ of cases and it is common among omphalophagus heterophagus twins. In omphalophagus and rachiphagus twins abdominal wall and spinal defects are commonly seen and these defects correspond to the site of attachment of the parasite., ${ }^{2,5}$ Spinal defects are inherent to rachipagus twins as heteropagus pairs result from union in the mid region of the neural tube. Rachiphagus twins also commonly have dysraphism. ${ }^{2} \mathrm{~A}$ similar picture was noted in the above case where the autosite demonstrated an open spinal dysraphism of lower thoracic and upper lumbar vertebra with a myelomeningocoele at the thoraco lumbar junction region.

\section{REFERENCES}

1. Edmonds LD, Layde PM. Conjoined twins in the United States, 19701977. Teratology 1982; 25:301-8.

2. Sharma G, Sheila S, Mobin N, Lypka M, Urata M. Heteropagus (parasitic) twins: a review. Journal of Pediatric Surgery 2010; 45, 2454-2463.

3. Husain AN, Muraskas J, Lambert G, et al. Parasitic conjoined twins with omphalocele and tetralogy of Fallot. Pediatric Pathology 1989;9: 321-8

4. Cury EK, Schraibman V. Epigastric heteropagus twinning. Journal of Pediatric Surgery 2001;36: E11-3.

5. Dar SH, Liaqat N, et al. An Epigastric Heteropagus Twin with Ruptured Giant Omphalocele. Journal of Neonatal Surgery 2014;3(2):23 
